\title{
O RISCO JUDICIAL DA FORÇA DO DEPOIMENTO DA VÍTIMA NO ÂMBITO DO CRIME DE ESTUPRO DE VULNERÁVEL
}

\author{
THE JUDICIAL RISK OF THE FORCE OF THE VICTIM'S WITNESS IN THE VULNERABLE RAPE CRIME
}

Ana Maria Moraes de Brito ${ }^{1}$

1 Advogada-OAB/PA.

\author{
"A primeira igualdade, é a justiça" \\ (Victor Hugo)
}

RESUMO: O que se propõe neste artigo é analisar os critérios de valoração da prova no crime de estupro pelo Superior Tribunal de Justiça. A principal questão é: Qual o valor do depoimento da vítima como prova substantiva no crime de estupro, conforme hermeneuticamente assentada por este tribunal? Primeiramente se buscou fazer análise dos tipos de estupro e suas peculiaridades. Em seguida foi averiguado os posicionamentos dos Tribunais sobre o tema, em especial em relação ao Supremo Tribunal Federal, que tem pacificado o entendimento de que o depoimento da vítima possui grande valor probatório.

Palavras-chave: Prova. Decisão Judicial. Estupro.

\begin{abstract}
The purpose here is to analyze the criteria for valuation of evidence in the crime of rape by the Superior Court of Justice. The question to be answered is: What is the value of the victim's testimony as substantive evidence in the crime of rape, as hermeneutically settled by the Superior Court of Justice? Firstly, we sought to analyze the types of rape and their peculiarities. Then, we sought to ascertain the positions of the Courts on the subject, especially in relation to the Federal Court of Justice, which has pacified the understanding that the victim's testimony has great probative value.
\end{abstract}

Keywords: Proof. Judicial decision. Rape.

Sumário: Introdução - 1 A Vitima, a Acusação e as Falsas Memórias - 2 A Decisão Judicial em face do Crime de Estupro de Vulnerável - Considerações Finais - Referências

\section{INTRODUÇÃO}

O entendimento do Superior Tribunal de Justiça (STJ) vem tornando as decisões judiciais, sobretudo, no que tange aos crimes contra a dignidade sexual, que estão previstos no título VI do Código Penal (CP), do artigo 213 ao 234-A, Lei no um campo aberto para julgamentos possivelmente arbitrários. Isso porque, em muitos casos, e aqui se tratará da modalidade do crime de estupro de vulnerável, cuja previsão legal consta no artigo 217-A, será buscado demonstrar a fragilidade da utilização do depoimento como único meio de prova, considerando que os crimes sexuais em sua maioria são delitos praticados "às escuras" e muitas vezes sequer deixam vestígios que possam ser verificados em um laudo pericial.

O que se propõe aqui é analisar os critérios de valoração da prova no crime de estupro pelo STJ. Tal tema é de fundamental importância, haja vista que o referido tribunal pacificou o entendimento de que o depoimento das vítimas de estupro e assédio sexual possuem grande relevância para uma condenação. Essa interpretação, no entanto, atenta diretamente contra princípios basilares do direito penal, quais sejam, a presunção de inocência e o in dubio pro reo, os quais são meios de busca pela igualdade processual entre as partes. As discussões a respeito do problema se devem a crescente quantidade de casos em que se verifica, posteriormente a condenação, a ocorrência de falso depoimento, ou mesmo, o surgimento de uma falsa memória e a superveniente busca por um responsável do erro judiciário, que em geral é o Estado ou a 
suposta vítima.

A questão que se procura responder é: Qual o valor do depoimento da vítima como prova substantiva no crime de estupro, conforme hermeneuticamente assentada pelo STJ? Buscar-se-á então analisar qual a melhor maneira de promover decisões judiciais no âmbito do crime de estupro e, por consequência, garantir à vítima, ao réu e a sociedade, segurança e certeza jurídica, respeitando a lei e os princípios do direito.

A pesquisa está dividida em duas partes, na primeira, buscou-se fazer análise dos tipos de estupro e suas peculiaridades, demonstrando em cada caso, as razões pelas quais esses delitos exigem uma cautela redobrada por parte do julgador, no momento de analisar as provas e proferir sua decisão. Na segunda, buscou-se averiguar os posicionamentos dos Tribunais sobre o tema, em especial em relação ao STJ, que tem pacificado o entendimento de que o depoimento da vítima possui grande valor probatório.

\section{A VITIMA, A ACUSAÇÃo E AS FALSAS MEMÓRIAS}

A vítima é, segundo Nucci (2011), o titular do bem jurídico protegido pelo tipo penal incriminador e, em razão disso, é também o interessado pela punição do agente causador da ofensa sofrida. É por essa razão que é possível concluir que o ofendido é uma figura do processo tão parcial quanto o acusado, haja vista a sua assunção do ônus de provar aquilo que está imputando ao acusado. Considera-se assim, que as suas declarações e atos podem estar eivado por todo tipo de emoções e interesses (ALTAVILLA, 1981).

Assim, antes de entender de que maneira ocorre o crime de estupro de vulnerável, previsto no artigo 217-A do CP Brasileiro, é necessário compreender de que forma são avaliados os depoimentos das vítimas nessa modalidade criminosa. Nesse tipo penal, o depoimento se torna um importante meio de prova, haja vista que se trata de um crime praticado às escuras e que poucas vezes deixam vestígios (TÁVORA \& ALENCAR, 2012).

Como é ponto pacífico a matéria referente as declarações do ofendido estão previstas no artigo 201 do CPP, determinando que o ofendido deve narrar as circunstâncias do evento criminoso. Essa previsão legal assume o condão de especificar os procedimentos realizados para o registro do depoimento do ofendido. Desse modo, o $\int 1^{\circ}$, deste artigo, assegura que se o ofendido for intimado a depor e se ausenta de forma injustificada, a autoridade policial ou a judiciária tem o poder de determinar a sua condução coercitiva (BRASILEIRO DE LIMA, 2012).

Já o $\int 2^{\circ}$ tem o viés de garantir que o ofendido seja comunicado dos atos processuais de prisão ou liberdade do acusado, designação de audiência, prolação de sentença ou acórdãos que a mantenham ou modifiquem. Essa comunicação deve ser feita em seu endereço ou por meio de e-mail, conforme o $\int 3^{\circ}$ do mesmo artigo.

Caso seja verificado pelo juiz que a presença do acusado esteja de alguma forma constrangendo a vítima, é possível que haja um espaço reservado para que se sinta à vontade em prestar seu depoimento (BRASILEIRO DE LIMA, 2012). Os $\iint 4^{\circ}$ e $5^{\circ}$ do artigo 201 do CP asseguram que o ofendido tenha um espaço reservado para prestar o seu depoimento, bem como o juiz poderá encaminhá-lo a uma equipe multidisciplinar, de forma a facilitar a sua oitiva.

Desse modo, o $\int 6^{\circ}$ garante que o juiz deve tomar as providencias necessárias para preservar a intimidade, a vida privada, honra e imagem da vítima, assegurando que esta não seja de qualquer forma exposta aos meios de comunicação. A Lei no 13.431 de 2017 traz a previsão legal de direitos e garantias das crianças e adolescentes que são vítimas ou testemunhas de violência, em consonância com o artigo 227 da Constituição da República Federativa do Brasil (CRFB), que determina,

Art. 227. É dever da família, da sociedade e do Estado assegurar à criança, ao adolescente e ao jovem, com absoluta prioridade, o direito à vida, à saúde, à alimentação, à educação, ao lazer, à profissionalização, à cultura, à dignidade, ao respeito, à liberdade e à convivência familiar e comunitária, além de colocálos a salvo de toda forma de negligência, discriminação, exploração, violência, crueldade e opressão (BRASIL, CONSTITUIÇÃO FEDERAL/1988, Art. 227). 
Os artigos de $7^{\circ}$ a 12 da Lei n 13.431 , de 2017 asseguram as crianças e adolescentes o direito a escuta especializada e ao depoimento especial. Assim, esses procedimentos, previstos nos artigos $7^{\circ}$ e $8^{\circ}$ da referida lei, consistem em:

Art. $7^{\circ}$ Escuta especializada é o procedimento de entrevista sobre situação de violência com criança ou adolescente perante órgão da rede de proteção, limitado o relato estritamente ao necessário para o cumprimento de sua finalidade.

Art. $8^{\circ}$ Depoimento especial é o procedimento de oitiva de criança ou adolescente vítima ou testemunha de violência perante autoridade policial ou judiciária.

De acordo com Santos e Coimbra (2017), as propostas da referida lei são de que o depoimento ocorra apenas uma única vez; o mais cedo possível e em sala separada com o acompanhamento de um profissional capacitado, em especial, psicólogos ou assistentes sociais. O intuito é fazer com que a vítima se sinta confortável em prestar o seu depoimento.

Conforme Coimbra (2014) o procedimento deve ser conduzido por profissionais com formação específica para lidar com crianças e adolescentes, que tenham informações sobre o processo, em local adequado, onde devem ser feito o registro de todo o processo, para que as informações passem a compor o processo judicial. Assim, o que se busca é garantir que a criança ou adolescente como parte em um processo judicial possam oferecer ao juiz um depoimento que lhe permita chegar próximo à reconstituição dos fatos ocorridos, considerando as limitações decorrentes da idade, do medo e da insegurança da criança. O crime de estupro de vulnerável está previsto no artigo 217-A do CP, conforme segue:

Art. 217-A. Ter conjunção carnal ou praticar outro ato libidinoso com menor de 14 (catorze) anos: Pena - reclusão, de 8 (oito) a 15 (quinze) anos.

$\int 1^{\circ}$ Incorre na mesma pena quem pratica as ações descritas no caput com alguém que, por enfermidade ou deficiência mental, não tem o necessário discernimento para a prática do ato, ou que, por qualquer outra causa, não pode oferecer resistência.

$\$ 2^{\circ}(\mathrm{VETADO})$

$\int 3^{\circ}$ Se da conduta resulta lesão corporal de natureza grave:

Pena - reclusão, de 10 (dez) a 20 (vinte) anos.

$\int 4^{\circ}$ Se da conduta resulta morte:

Pena - reclusão, de 12 (doze) a 30 (trinta) anos.

$\int 5^{\circ}$ As penas previstas no caput e nos $\iint 1^{\circ}, 3^{\circ}$ e $4^{\circ}$ deste artigo aplicam-se independentemente do consentimento da vítima ou do fato de ela ter mantido relações sexuais anteriormente ao crime. (Brasil, Decreto-Lei $n^{\circ}$ 2.848. 07/12/1940. Art. 217-A $\int S 1^{\circ}$ ao $5^{\circ}$ ).

Essa modalidade criminosa tem como sujeito passivo o menor de 14 (quatorze) anos ou a pessoa que esteja em condição especial de vulnerabilidade, nos casos de enfermidade ou deficiência mental, ou que não tenha condições de ter o discernimento necessário para a prática do ato, em condição tão extrema de vulnerabilidade que o impossibilite de oferecer resistência (BITENCOURT, 2018).

O artigo 217-A consta no título VI do CP, referente aos crimes contra a dignidade sexual, determina que são vulneráveis os menores de 14 anos que não possuem liberdade sexual pois não há, nessa idade, a plena disponibilidade do exercício desse direito. Desse modo, o que a referida previsão legal busca é garantir a esse menor o desenvolvimento normal da sua personalidade e sem traumas psicológicos, assegurando que este tenha base psicossocial para deliberar livremente sobre a sua sexualidade futura (BITENCOURT, 2018).

De modo semelhante, o artigo 217-A busca proteger os enfermos, deficientes mentais ou aqueles que se encontram impossibilitados de discernir sobre seus atos ou de apresentar resistência contra a prática de atos sexuais, assegurando a sua intangibilidade sexual, ou ainda, nesse último caso, defender a liberdade de autodeterminação, comprometida em razão da absoluta incapacidade de resistir (DE JESUS, 2014). Neste sentido Bitencourt (2018) afirma que 
Em síntese, pode-se afirmar que há três modalidades de vulnerabilidade: a) real (do menor de 14 anos); equiparada (do enfermo ou deficiente mental); por interpretação analógica (quem, por qualquer outra causa, não pode oferecer resistência), que, repetindo, foi prevista somente neste art. 217-A (BITENCOURT, 2018, p. 107).

Assim, o crime de estupro de vulnerável é considerado crime hediondo ${ }^{1}$, em razão de ser um crime de grande repúdio social. A esse respeito Sznick (2011) Afirma que o legislador ao definir o crime hediondo e determinar sua punição estava respondendo a um anseio da população brasileira, que observava com preocupação o crescimento de certas modalidades criminosas, como sequestro e latrocínio, causadores de muita inquietação social. Conforme se verifica na redação do caput do artigo referente ao crime de estupro e de acordo com Greco (2014), a consumação do tipo penal deste delito ocorre na presença dos seguintes requisitos: a) ter conjunção carnal; b) praticar ato libidinoso diverso da conjunção carnal; c) com menor de 14 anos.

No entanto, para que se configure o referido crime, conforme aduz Greco (2014), é necessário que o agente praticante do delito tenha conhecimento de que a vítima é menor de 14 anos, além de ter o dolo de praticar o ato sexual, pois em caso contrário, poderá ser alegado erro de tipo ${ }^{2}$ sob a conduta praticada, descaracterizando o crime (GRECO, 2014). Na previsão legal do estupro de vulnerável, em seus $\iint 3^{\circ}$ e $4^{\circ}$, do referido artigo há as modalidades qualificadas do referido crime, referentes a prática do ato descrito no caput tendo como resultado lesão corporal grave ${ }^{3}$ ou morte, respectivamente. Para cada um dos casos, o legislador aplicou uma pena mais severa, considerando o resultado mais gravoso do ato, conforme segue:

Essas qualificadoras retratam crimes preterdolosos ou preterintencionais, vale dizer, atos que pressupõe que tenha o agente atuado com dolo no movimento inicial (in casu, na realização do ato libidinoso) e com culpa no resultado agravador (lesão grave ou morte). Se houve dolo (direto ou eventual) quanto à produção de tais eventos, haverá concurso material de crimes (entre o estupro de vulnerável e a lesão corporal grave ou homicídio) (DE JESUS, p. 2014, p. 164).

A responsabilidade pela ação penal no crime do artigo 217-A é pública e incondicionada a representação do ofendido, tendo em vista a vulnerabilidade da vítima e em conformidade com o artigo 225 do CP (GRECO, 2014). A partir deste ponto essa análise tem por parâmetro as ideias e as reflexões contido na obra: Prova Penal e Falsas Memórias, de autoria de Cristina Di Gesu, por ser este um trabalho que tem grande importância neste estudo e na explicação deste tema. Inicialmente a autora destaca o seguinte:

Em se tratando de processo penal, embora se leve em consideração todos os princípios regentes da prova, em especial a presunção de inocência e in dubio pro reo, veem inúmeras decisões condenatórias fundamentadas exclusivamente na prova oral, principalmente na palavra da vítima, quando a infração não deixa resquícios materiais, como corre nos delitos de atentado violento ao pudor (DI GESU, 2014, p. 154).

A importância da memória das partes envolvidas no processo está relacionada ao procedimento de reconstrução do fato delituoso, diante da ausência de outros meios de prova. Há, portanto, uma maior necessidade de análise das provas orais, considerando os inúmeros erros judiciais que decorrem dos testemunhos falsos ou equivocados (DI GESU, 2014). Uma importante diferenciação a ser feita, observada por Lopes Junior (2016), afirma que as falsas memórias são diferentes da mentira, haja vista que na primeira, o

\footnotetext{
1 Os crimes hediondos encontram-se no rol do artigo $1^{\circ}$ da lei 8.072 de 1990, os quais são enumerados de forma taxativa. Tratase dos crimes inafiançáveis, insuscetíveis de graça ou anistia. São, desse modo, os crimes considerados mais perigosos e prejudiciais à sociedade (PEREIRA, 2018).

${ }^{2}$ Erro de tipo segundo Nucci (2011) é o engano a respeito de um dos elementos que compões o que a lei determina como conduta proibida, excluindo o seu dolo, ou seja, descaracterizando a vontade do sujeito em cometer um crime.

${ }_{3}$ Previsto no artigo $129, \iint 1^{\circ}$ e $2^{\circ}$, do CP.
} 
depoente acredita que aquilo que está relatando é verdade, enquanto na segunda, se trata de um ato consciente de que a pessoa está manipulando a veracidade das informações prestadas.

A falsificação da memória tem como surgimento não apenas por meio do inconsciente ou do involuntário da pessoa, mas também pode ser dirigida por um terceiro, que de maneira desinformada, acaba por alterar a memória da pessoa a quem se dirige, de forma sugestiva (DI GESU, 2014). No que diz respeito ao processo penal, a prova oral está sujeita a diversos tipos de contaminação, a qual está submetida a diversos tipos de constrangimento.

Assim, Di Gesu (2014) afirma que a procura desmedida por uma "verdade real" acaba influenciando a memória das pessoas envolvidas no processo, mesmo antes dele. É impossível guardar partes em uma "redoma de vidro", protegendo o seu depoimento de riscos endógenos e exógenos ao processo. Nesta senda, a autora elenca alguns fatores de contaminação da prova oral, tornando-a uma prova frágil para ser considerada isoladamente. A primeira dificuldade elencada é o transcurso do tempo. A CRFB, em seu artigo $5^{\circ}$, inciso VXXVIII, traz a previsão do princípio da razoável duração do processo, garantindo o dever de celeridade da tramitação processual.

A razoável duração do processo deve ser considerada para assegurar o respeito a todas as partes do processo. Aqui, se deve adotar tanto a perspectiva dos direitos do réu, de forma a não prolongar indefinidamente o peso de estar sob o julgamento e a reprovação da sociedade, mas também, é necessário compreender que o transcurso do tempo favorece o esquecimento dos detalhes do acontecimento a ser relatado pela vítima. Os detalhes que antes estavam claros na memória, acabam por se tornar cada vez mais distante e a cada evocação da lembrança, essa pode acabar sendo modificada (DI GESU, 2014).

O hábito e a rotina são elencados como outros fatores de contaminação da prova. Nessas situações, as memórias podem ser adquiridas por meio de associação de estímulos e de um estímulo a uma resposta. Quando se está habituado a alguma prática, se é levado a interromper a memória, posto que o cérebro da pessoa é levado a não fazer esforço, em razão de já estar acostumado (DI GESU, 2014).

Além disso, um outro fator de contaminação é a linguagem e o método do entrevistador, o qual tem potencial capacidade de influenciar aquilo que a testemunha ou a vítima efetivamente sabem sobre o delito, no intuito de orientá-los a seguir a sua hipótese, geralmente acusatória Di Gesu (2014). Posto que quando o entrevistador está diante da vítima ou da testemunha colhendo as informações relativa aos fatos do delito, é muito comum este imputar aos relatos feitos a sua própria convicção, desprezando as respostas incompatíveis com a sua hipótese, tornando a prova totalmente viciada (DI GESU, 201). Segundo a autora o que se percebe e o seguinte.

Com efeito, o viés do entrevistador pode ser observado não somente através do modo como os questionamentos são formulados, mas também em comportamentos sutis, como um sorriso, um movimento de cabeça ou pelo tom de voz (acusatório, desculpador ou neutro). Segundo pesquisas realizadas sobre o tema, a recordação das crianças é altamente precisa quando as hipóteses dos entrevistadores são corretas, ou seja, condizentes com a realidade; contudo, quando as suposições são incorretas, isto é, dissociadas da realidade, as crianças mais jovens, especialmente, produzem uma quantia significativa de informações inexatas (DI GESU, 2014, p. 178).

Logo, é comum haver a necessidade de repetição das entrevistas, e dentro delas, a constante repetição de perguntas. Esses são outros fatores que tornam a prova um campo aberto para a inserção de convicções do entrevistador, retirando a sua fidedignidade. Quando há a repetição de entrevistas, volta-se ao problema do tempo, pois o seu decurso favorece o enfraquecimento da memória original. Ademais, a repetição de perguntas pode vir a ser empregada com o intuito de verificar a consistência dos depoimentos, mas muitas vezes pode vir a ser utilizada pelo entrevistador para induzir estereótipos ao entrevistado (DI GESU, 2014). A autora continua afirmando que não se deve descartar a interferência da impressa sensacionalista, em caso de grande repercussão, que podem influenciar as pessoas envolvidas no processo.

E por fim, a autora apresenta como fator de grande contribuição para a contaminação da prova o 
subjetivismo do julgador. Embora o magistrado deva sempre pautar sua postura de imparcialidade, esta não deve se confundir com neutralidade, que diz respeito a projeção de experiências, sentimentos, vivências pessoais do julgador, muito difíceis de estarem ausentes em uma decisão. "Neste ínterim, seria utópico pensar em prolação de decisões judiciais dissociadas de valores sociais, de paradigmas históricos, filosóficos e psicológicos” (DI GESU, 2014, p. 187).

A autora afirma, ainda, que a sentença reflete a postura ideológica do magistrado, podendo este adotar uma atuação meramente de subsunção da norma ao fato ou uma postura politizada, guardiã dos direitos fundamentais. Essa situação reflete substancialmente que a avaliação da prova, embora não deva ser feita de forma discricionária e observando o sistema do livre convencimento motivado do juiz, pode vir a ser contaminada pelo subjetivismo do julgador, conforme a postura que este adota no momento de proferir a sua decisão. A todo momento, sem dúvida, a sentença está sujeita as vivencias e posturas ideológicas do magistrado no momento de analisar uma prova (DI GESU, 2014).

Portanto, é necessário ter muita cautela quando se está lidando com o depoimento da vítima como único meio de prova, principalmente quando se trata da oitiva de uma criança, especialmente nos casos de crimes contra a liberdade sexual na modalidade que não deixa vestígios. Não se trata de demonizar o depoimento da vítima, mas de ter cautela para não haver o seu endeusamento.

\section{A DECISÃO JUDICIAL EM FACE DO CRIME DE ESTUPRO DE VULNERÁ- VEL}

Uma questão importante nesta reflexão é determinar as razões pelas quais a palavra da vítima necessita de uma rigorosa precaução, quando usada isoladamente em uma condenação. Para responder à questão: qual o valor do depoimento da vítima nas decisões do Superior Tribunal de Justiça? Juntamente com as questões correlatas: a) qual o critério utilizado para valorar esse tipo de prova e b) quais os prejuízos decorrentes disso? A pesquisa jurisprudencial visou identificar de que forma o STJ entende o valor probatório do depoimento da vítima de estupro de vulnerável. Para tanto, foi utilizado a ferramenta pesquisa pronta presente no site do STJ, que reuniu decisões de grande repercussão referentes ao tema. Em grande parte de suas decisões, o tribunal entende que em virtude desse crime ser praticado na clandestinidade, muitas vezes sem a presença de testemunhas, o depoimento da vítima passa a ter grande relevância.

Para uma compreensão mais completa da forma como o tribunal aplica o seu entendimento à questão, serão analisadas duas decisões: a primeira é referente a um pedido de Habeas Corpus e a outra é de um Recurso Ordinário em Habeas Corpus. Em ambos os casos, o relator foi Ministro Ribeiro Dantas e todas estão presentes na ferramenta Pesquisa Pronta, no site do STJ. O primeiro caso é referente ao Habeas Corpus 410.186 - TO 2017/0187114-4, cuja ementa é a seguinte:

PENAL. HABEAS CORPUS SUBSTITUTIVO DE RECURSO PRÓPRIO. INADEQUAÇÃO. ESTUPRO DE VULNERÁVEL. ABSOLVIÇÃO. IMPROPRIEDADE DA VIA ELEITA. INCIDÊNCIA DA CAUSA DE AUMENTO DO ART. 226, II, DO CP. RÉU ASCENDENTE DA VÍTIMA. MAIORES INCURSÕES SOBRE O TEMA QUE DEMANDARIAM REVOLVIMENTO FÁTICOPROBATÓRIO. DESPROPORCIONALIDADE DA PENA. INSTRUÇÃO DEFICIENTE. WRIT NÃO CONHECIDO. 1. Esta Corte e o Supremo Tribunal Federal pacificaram orientação no sentido de que não cabe habeas corpus substitutivo do recurso legalmente previsto para a hipótese, impondo-se o não conhecimento da impetração, salvo quando constatada a existência de flagrante ilegalidade no ato judicial impugnado. 2. Se as instâncias ordinárias, mediante valoração do acervo probatório produzido nos autos, entenderam, de forma fundamentada, ser o réu autor do delito descrito na exordial acusatória, a análise das alegações concernentes ao pleito de absolvição demandaria exame detido de provas, inviável em sede de writ. 3. A jurisprudência pátria é assente no sentido de que, nos delitos contra a liberdade sexual, por frequentemente não deixarem vestígios, a palavra da vítima tem valor probante diferenciado. Precedentes. 4. O simples fato de o laudo pericial não ter definido a data em que a criança contraiu o vírus HPV, bem como a alegada ausência de elemento de prova apto a demonstrar que o réu é portador 
de tal vírus não induzem à sua absolvição por carência de prova de autoria delitiva, nos moldes do defendido pela impetrante. 5. Conforme o consignado na sentença, o paciente é pai do genitor da vítima, tratando-se, portanto, de seu ascendente para fins do art. 226, II, do CP. Oportuno destacar, ainda, que a condição de ascendente deve ser reconhecida mesmo que a filiação advenha da adoção, a teor do art. 227, $\int 6^{\circ}$, da Constituição da República, o que torna, de per si, despicienda a realização de exame de DNA para a comprovação do vínculo parental entre o agente e a vítima. Além disso, dúvida não há acerca do papel de autoridade exercido pelo agente, o qual se valeu de sua condição de avô para submeter a menor a prática do ato libidinoso, enquanto ela pernoitava em sua casa, circunstância bastante para o reconhecimento da causa de aumento de pena. 6. Para desconstituir a conclusão das instâncias ordinárias, as quais reconheceram a incidência de aumento do art. 226, II, do CP, seria necessário revolver as provas amealhadas nos autos, providência que não se coaduna com a via do habeas corpus. 7 . Em sede de habeas corpus, a prova deve ser pré-constituída e incontroversa, cabendo ao impetrante apresentar documentos suficientes à análise de eventual ilegalidade flagrante no ato atacado. Na espécie, quanto à alegada desproporcionalidade da pena, o feito não foi instruído com cópia do inteiro teor do acórdão proferido no julgamento do apelo defensivo, peça imprescindível para análise da impetração, máxime por ter havido revisão dos parâmetros dosimétricos pela Corte de origem. 8. Writ não conhecido.

Nesse caso, o babeas corpus foi impetrado em favor de G.E. de S. contra acórdão do Tribunal de Justiça do Estado de Tocantins, que reconheceu como vítima a sua neta, de nove anos de idade à época dos fatos. Conforme traz a sentença, a vítima indicou o réu como o responsável pela prática de ato libidinoso diverso da conjunção carnal, a saber, cópula anal, com possível contaminação do vírus HPV, no ano de 2002.

O réu foi acusado e condenado pelo crime de atentado violento ao pudor, previsto no artigo 214 do CP, revogado pela Lei de $\mathrm{n}^{\circ} 12.015 / 09$, tendo sido aplicado em virtude de ser mais benéfico ao réu se comparado ao crime de estupro de vulnerável, previsto no artigo 217-A do CP. Cumulado a imputação do crime de atentado violento ao pudor, foi aplicado ao réu a causa de aumento de pena prevista no artigo 226, inciso II, haja vista que este era avô da vítima.

No pedido, a parte afirma que a condenação se baseou em provas insuficientes, afirmando que havia veementes dúvidas a respeito da autoria do delito. Isso se deve em razão de que o crime havia supostamente sido praticado no ano de 2005 e a denúncia só foi feita em 2008, tendo dificultado em demasia a produção de provas concisas.

A decisão do STJ se quedou em afirmar que em sede de habeas corpus, não há a reanálise das provas produzidas durante a instrução processual. Assim, limitaram-se a afirmar que, em face disso, a palavra da vítima possui "valor probante diferenciado", conforme consta na decisão.

Neste caso, a vítima afirmou que havia contraído HPV em decorrência da prática de ato libidinoso diverso da conjunção carnal. Há época do ocorrido, foi realizado um exame pericial que constatou a presença de HPV, mas o exame não foi feito com o réu para afirmar se ele havia sido o responsável pela contaminação da doença. Além disso, o referido laudo se mostrou inconclusivo em apontar o período do suposto contato sexual até o aparecimento dos sintomas da doença. A vítima escondeu a história por anos, tendo revelado os fatos apenas três anos após a suposta prática do crime, fato que culminou em toda a dificuldade de investigações do caso.

O tribunal entendeu que as inconsistências referentes ao laudo pericial não eram suficientes para retirar do réu a autoria do delito, considerando que a vítima o havia apontado como autor do crime e sua palavra possui grande relevância, não havendo o que se falar em carência de provas. Esta decisão se mostra importante em razão de estar presente na ferramenta Pesquisa Pronta e por demonstrar de forma exemplificada a maneira pela qual o STJ aplica o seu entendimento, expondo de forma clara e direta que o depoimento da vítima possui elevada importância em um contexto de provas fracas, em um processo prejudicado pelo silêncio da suposta vítima por muitos anos, motivo que culminou na dificuldade de reconstrução dos fatos.

O outro caso selecionado para demonstrar a aplicação da compreensão do STJ é o Habeas Corpus 
94.036 - RR 2018/0011343-1, que tem a seguinte ementa:

PROCESSO PENAL. RECURSO ORDINÁRIO EM HABEAS CORPUS. ESTUPRO DE VULNERÁVEL. JUSTIFICAÇÃO CRIMINAL. PLEITO DE PRODUÇÃO DE PROVA PARA A PROPOSITURA DE REVISÃ̃O CRIMINAL. RETRATAÇÃO DA MENOR. INSUFICIÊNCIA PARA A COMPROVAÇÃO DA INOCÊNCIA DO RÉU. CONDENAÇÃO BASEADA EM DIVERSAS PROVAS COLHIDAS NO CURSO DO PROCESSO-CRIME. ÓBICE AO REVOLVIMENTO FÁTICO-PROBATÓRIO. IMPROPRIEDADE DA VIA ELEITA. RECURSO DESPROVIDO. 1. Hipótese na qual as instâncias ordinárias entenderam que a condenação do réu foi baseada em diversos elementos de convicção colhidos durante a instrução criminal, não sendo possível, portanto, pretender a absolvição do apenado com fundamento em prova testemunhal a ser produzida através de justificação criminal. Além disso, foi afirmado que a vítima prestou inúmeros depoimentos no curso do processocrime, tendo sido devidamente acompanhada por psicóloga, sendo que a nova ouvida causaria desnecessário constrangimento à adolescente, ainda menor de 18 anos. 2. Ainda que a retratação da vítima possa embasar a propositura de revisão criminal, configurando prova nova para fins do art. 621, III, do CPP, importa reconhecer que o seu depoimento deverá ser apto a conduzir à absolvição do sentenciado ou, ainda, à redução da pena a ele definida. No caso, tendo sido reconhecida a insuficiência de tal prova pelo Juízo processante para a pretendida comprovação da inocência do ora recorrente, com base no contexto fático-probatório dos autos, para infirmar essa conclusão seria necessário revolver as provas produzidas no curso do processo-crime, providência que não se coaduna com a via no mandamus. 3. Recurso ordinário desprovido.

Nesse processo, trata-se de um recurso ordinário em habeas corpus interposto por L.L de P. contra o Tribunal de Justiça do Estado do Pará, que o condenou a pena de 8 anos, 10 meses e 25 dias de reclusão, em regime fechado, pela suposta prática do crime previsto no artigo 217-A do CP. Conforme o relatório da decisão, o apenado ajuizou um pedido de justificação criminal em razão da retratação da vítima, que afirmou ter se arrependido de ter o acusado de cometer o crime, declarando que este não ocorreu. O réu solicitou ao juízo a quo a colheita de novo depoimento da vítima, o qual negou seu pedido, tendo este sido igualmente rejeitado pelo Tribunal de Justiça.

O réu buscava então apresentar uma justificação criminal com o intuito de instruir uma revisão criminal, tendo como fundamento a retratação da vítima. Desse modo, tanto o magistrado de primeiro grau quanto o colegiado a quo decidiram afirmando que além do depoimento da vítima, havia outros elementos de convicção, tendo apontado exclusivamente que esta havia sido ouvida inúmeras vezes. Em face disso, o STJ negou provimento ao recurso ordinário, em razão da impossibilidade de produção de provas novas nessa fase processual e reforçando igualmente o valor probatório da palavra da vítima.

A importância dessa decisão se faz no intuito de demonstrar que, mesmo diante da retratação da vítima, afirmando que não havia sido praticado nenhum crime contra si, o tribunal permaneceu aplicando maior valor ao depoimento que conferia ao réu a culpa pelo crime. Verifica-se que há, de fato, um valor maior ao depoimento da vítima, principalmente quando se trata se uma prova acusatória. Em razão dos casos apresentados é necessário que se faça uma analisar dos prejuízos decorrentes dessa postura, não apenas do STJ, mas do judiciário como um todo, haja vista que este não deve apenas aplicar mais peso a palavra de uma das partes do processo, mas, buscar sempre um olhar imparcial, sob a ótica dos direitos de todos os indivíduos nele envolvidos.

Primeiramente, será tratado o caso referente a um recurso especial de revisão criminal no 1.483 .934 - TO 2014/0252428-6, apresentado perante o STJ, cuja ementa consta a seguir:

REVISÃO CRIMINAL. ESTUPRO DE VULNERÁVEL. RETRATAÇÃO DA VÍTIMA. JUSTIFICAÇÃO JUDICIAL. PROVA RESULTANTE DUVIDOSA. IN DÚBIO PRO REO. INDENIZAÇÃO POR DANOS MORAIS. INOCORRÊNCIA. REVISÃO CRIMINAL PARCIALMENTE PROCEDENTE. 1. Em havendo a retratação da vítima, em procedimento de justificação judicial, com participação efetiva do membro do parquet, trata-se de prova nova que entra em contradição com as 
declarações prestadas pela vítima durante a instrução processual. (Artigo 621, II e III, do Código de Processo Penal) 2. As demais provas produzidas durante a instrução denotam tão somente indícios da ocorrência do fato. 3. Em não havendo outros elementos de prova substanciais a embasar o decreto condenatório, tendo sido a palavra da vítima o sustentáculo principal da r. sentença e do v. acórdão, a reforma das decisões é medida que se impõe, a fim de reconhecer a incidência do princípio in dubio pro reo. 4. Lado outro, não há que se cogitar em indenização a ser paga ao requerente pelo ente Público, vez que este não deu causa às versões falsas apresentadas pela vítima, tendo as decisões anteriormente proferidas obedecido o devido processo legal, respeitando-se todos os direitos e garantias da parte. 5. Revisão PARCIALMENTE PROVIDA, a fim de revogar o decreto condenatório, reconhecendo a absolvição do requerente por insuficiência de provas.

O recurso especial foi interposto ao STJ com o intuito de pugnar pela indenização estatal em razão de erro judiciário, haja vista que o recorrente R. M. da C. foi condenado pelo delito de estupro de vulnerável e após terem se passado três anos da condenação, a vítima se retratou, alegando que suas declarações prestadas na instrução processual foram inverídicas. O Tribunal a quo reconheceu a revisão criminal, aplicando o princípio do in dubio pro reo, absolvendo o réu de todas as imputações que lhe foram feitas na instrução criminal. O pedido inicial do réu constava o da absolvição por revisão criminal e que o estado o indenizasse por responsabilidade em razão de erro judiciário, nos termos do artigo 630 do Código de Processo Penal.

No entanto, o STJ negou o pedido do réu referente à indenização, afirmando que não havia erro imputável ao judiciário, afirmando que este teria decidido com base no "conjunto probatório harmônico, suficiente para embasar o decreto condenatório". A importância dessa decisão consiste em demonstrar que não há um tratamento aos direitos do réu igual ao que se busca garantir a vítima, esteja ela falando a verdade ou não. Aqui neste caso, embora tenha sido reconhecido o falso testemunho da vítima, a sua retratação em nada ensejava uma responsabilização estatal, afirmando que sua atuação foi baseada em "estrita lisura, respeitando a todos os direitos e garantias da parte", devendo o réu pleitear indenização apenas junto a quem o havia acusado indevidamente.

No entanto, não ficou demonstrado na decisão de que modo o judiciário teria se empenhado em esgotar as possibilidades probatórias do caso para ter a certeza da decisão condenatória que estava proferindo. Dentro deste tema há uma importante análise feita por Lopes Junior (2018). Para ele é necessário que sejam assumidos os riscos dessa ciência, não a compreendendo como uma verdade absoluta. Dessa forma, é necessário dar primazia a um sistema de garantias mínimas, de forma a empregar limites ao poder punitivo estatal. $\mathrm{O}$ autor afirma que,

Nessa linha, pensamos que se deve maximizar a eficácia das garantias do devido processo penal:

a) Jurisdicionalidade: especialmente no que tange ao juiz natural e à imparcialidade;

b) Princípio acusatório (ou dispositivo): fundando o sistema acusatório em conformidade com a Constituição;

c) Presunção de inocência: enquanto pré-ocupação de espações mentais (do julgador) e, portanto, no viés de "dever de tratamento" e "regra de julgamento";

d) Ampla defesa e contraditório: ainda que distintas, são duas garantias que mantêm íntima relação e interação, necessitando ser maximizadas no processo penal;

e) Motivação das decisões: especialmente no viés de legitimação do poder jurisdicional exercido e instrumento de controle contra o "decisionismo" e o arbítrio (LOPES JUNIOR, 2018, p. 83).

Nesse sentido, ao invés do mero positivismo, de aplicação da norma ao caso concreto, é necessário que as decisões sejam norteadas por um conteúdo ético e axiológico, lutando pela máxima eficácia dos direitos e das garantias individuais. No entanto, tais garantias se diferem totalmente de uma impunidade, devendo ser empregada como uma forma de respeito aos direitos e não como negligência (LOPES JÚNIOR, 2018). Por essa razão, ao tratar da análise do valor probatório do depoimento da vítima, é necessário compreender duas formas distintas a serem empregadas pelo judiciário ao valorar o depoimento da vítima, 
considerando tanto a possibilidade de um depoimento falso quanto a um surgimento de uma falsa memória.

Em se tratando de um falso depoimento, deve-se aplicar o conceito trazido por Greco (2016). Considerando que o crime de estupro em muitos casos não deixa vestígios é necessário aplicar o que a criminologia determina como sindrome de Potifar ${ }^{4}$. Em situações que o julgador está diante desse caso é necessário que ele busque ter a sensibilidade necessária para apurar os fatos relatados pela vítima, ou seja, deverá buscar comprovar a verossimilhança das alegações feitas. Para tanto, Seiça (1999) traz algumas alternativas para solucionar a difícil tarefa de impor filtros as declarações prestadas no processo, no intuito de verificar se o declarante falou a verdade ou se a sua percepção foi ferida ou manipulada de alguma forma.

A primeira modalidade é a técnica da contraprova (reprova), que consiste em buscar adquirir outras provas que forneçam a representação do fato exposto e que se pretende verificar. A partir do momento em que o fato passa pelo crivo de duas fontes probatórias independentes é possível conferir uma maior segurança a ele. A segunda técnica é a corroboração, onde afirma-se que na falta de dois meios probatórios em relação ao mesmo fato é necessário recorrer as técnicas que, não tendo o objeto o conteúdo da declaração probatória, assegurem a verificação da veracidade da alegação.

Trata-se de fatos que por si só não possuem relação com o processo, mas que de alguma forma influem de forma impactante nele. É o caso, por exemplo, de uma testemunha que não conhece a vítima, nem muito menos o acusado e que em nada ganha ou perde com o benefício ou malefício de qualquer um dos dois, mas tem conhecimento acerca dos fatos alegados e seu depoimento assegura uma maior segurança as provas produzidas no processo.

Uma terceira técnica é a verificação sobre as características da declaração on atendibilidade intrínseca, que determina que a sindicância exerce grande importância a respeito dos fatos narrados. Para isso, é necessário considerar fatores como a espontaneidade e a tempestividade da declaração, a sua constância e coerência interna, bem como a sua completude e verossimilhança decorrente da ausência de contraste com outros elementos probatórios. É necessário considerar ainda questões como o interesse processual, substancial e extrajudicial (como amizade, parentesco, remuneração, dentre outros). E por fim, a última técnica indicada pela autora é a que versa a respeito da verificação sobre a atendibilidade do declarante, que trata da necessidade de fiscalizar o próprio declarante, verificando a sua credibilidade, considerando a sua personalidade e a veracidade das suas declarações demonstrada em fases anteriores ao processo.

Para dirimir dúvidas acerca de depoimentos viciados em razão de uma falsa memória, Lopes Júnior (2016), como já discutido anteriormente neste trabalho, aponta algumas medidas que podem ser empregadas para diminuir os danos, dado que existem casos em que crianças e adolescentes, muitas vezes se utilizam da acusação por um suposto abuso sexual para fazer cessar violências físicas e psicológicas contra genitores, padrastos ou responsáveis. No entanto, a medida cabível nesse caso, não seria a acusação por um abuso sexual não cometido, e sim o afastamento do lar.

Diante de todo o exposto, Seiça (1999) aduz a respeito da exigência de fundamentação da decisão judicial, que não se deve em razão exclusivamente do controle ao abuso de poder, mas também, do convencimento da decisão e da capacidade do juiz impor a sua argumentação. Assim, a decisão por si só deve ser justa e parecer justa, destinando-se não apenas as partes, mas a toda sociedade. Para Monteiro (1997), o contrário disso é uma renúncia à busca pela certeza no processo e na apreciação da prova, passando o julgador a acreditar que toda a sua convicção interior é suficiente para formar um convencimento acerca da culpabilidade ou não do réu. A íntima convicção do julgador é a dúvida que permanece no seu íntimo, mas que o impõe e de todo modo é necessário pronunciar um veredito.

\footnotetext{
${ }^{4}$ Greco (2016, p. 55) faz explicação a respeito dessa denominação narrando a história bíblica de José, capítulo 39, versículos 6 a 20, de onde surgiu a história da mulher de Potifar, a qual é aplicada aos dias de hoje nos casos em que a vítima acusa injustamente o réu, com o mero intuito de vingar-se ou causar mal injusto.
} 


\section{CONSIDERAÇÕES FINAIS}

As decisões judiciais condenatórias nos crimes sexuais contra vulnerável devem, mais do que qualquer outro crime, ser analisado por um juiz, apresentar uma cautela maior em sua resolução, em razão de ser uma modalidade de delito praticado na clandestinidade e que, em muitas vezes, sequer deixa vestígios. Além disso, a pessoa da vítima é aquela que sofreu um dano psicológico, físico ou moral e que por uma razão determinada, imputa um fato criminoso a outra pessoa. Foi visto, ainda, que existem diversos princípios que norteiam o direito penal e processual brasileiro e, dentre eles, merece destaque a presunção de inocência e o in dubio pro reo. Assim, em caso de dúvidas a respeito da autoria do delito faz-se absolutamente necessário que o réu seja absolvido por falta de provas.

Ocorre que, de acordo com o entendimento pacificado do STJ, o depoimento da vítima nos casos de crimes sexuais passou a ter relevantíssimo valor probatório, havendo a possibilidade inclusive de condenação do réu mesmo que ausentes outros meios de prova. Nesse sentido, entende-se que tal entendimento gera um abandono do sistema da livre convicção motivada do juiz, o qual passou a adotar um sistema de tarifação das provas.

No entanto, cabe ao judiciário em sua totalidade empenhar-se em unificar e concretizar as medidas necessárias para aplicar a todo o direito, principalmente ao Direito Penal, em razão de ser a ultima ratio, uma maior segurança, certeza e previsibilidade, acerca do modo de investigação e aplicação da pena. Assim, as reais vítimas de estupro poderão ter a certeza da punição de seu agressor, bem como os inocentes saberão que a justiça será sempre respeitada.

\section{REFERÊNCIAS}

ALTAVILLA, Enrico. Psicologia Judiciária. Coimbra: Armênio Amado, 1981.

BITENCOURT, Cezar Roberto. Tratado de Direito Penal: parte especial, v. 4. 12. Ed. São Paulo: Saraiva. 2018.

BRASIL. Constituição (1988). Constituição da República Federativa do Brasil. Brasília, DF: Senado Federal. Disponível em: <http://www.planalto.gov.br/ccivil_03/Constituicao/Constituicao.htm>. Acesso em: 03 dezembro 2018.

. Decreto-Lei no 2.848 de 1940. Código Penal Brasileiro. Rio de Janeiro. Disponível em: < http:// www.planalto.gov.br/ccivil_03/decreto-lei/Del2848compilado.htm>. Acesso em: 03 dezembro 2018.

. Decreto-Lei no 3.689 de 1941. Código de Processo Penal Brasileiro. Rio de Janeiro. Disponível em: <http://www.planalto.gov.br/ccivil_03/Decreto-Lei/Del3689.htm>. Acesso em: 03 dezembro de 2018.

. Lei 13.431 de 2017. Estabelece o sistema de garantia de direitos da criança e do adolescente vítima ou testemunha de violência e altera a Lei no 8.069, de 13 de julho de 1990 (Estatuto da Criança e do Adolescente). Brasília, DF. Disponível em: < http://www.planalto.gov.br/ccivil_03/_Ato 20152018/2017/Lei/L13431.htm>. Acesso em: 03 dezembro 2018.

BRASILEIRO DE LIMA, Renato. Manual de Processo Penal, vol. I. 2. ed. Niterói, RJ: Impetus. 2012. COIMBRA, José César. Depoimento especial de crianças: um lugar entre proteção e responsabilização? Psicol. cienc. prof., Brasília, v. 34, n. 2, p. 362-375, junho 2014.

DI GESU, Cristina. Prova Penal e Falsas Memórias. 2. Ed. Porto Alegre: Livraria do Advogado Editora, 2014.

DE JESUS, Damásio. Direito Penal: parte especial. 21. Ed. São Paulo: Saraiva.2014.

GRECO, Rogério. Curso de Direito Penal, v. III. 11. ed. Niterói, RJ: Impetus. 2014.

2016.

Direito Penal do Equilíbrio: uma Visão Minimalista do Direito Penal. 9.ed. Niterói, RJ: Impetus.

LOPES JÚNIOR, Aury. Direito Processual Penal. 13. ed. São Paulo: Saraiva. 2016. 
Fundamentos do Processo Penal: Introdução Crítica. 4.ed. São Paulo: Saraiva, 2018.

MONTEIRO, Cristina Líbano. Perigosidade de Inimputáveis e In Dubio Pro Reo. Boletim da Faculdade de Direito. Univ. de Coimbra. Coimbra Editora, 1997.

NUCCI, Guilherme de Souza. Manual de Direito Penal: parte geral: parte especial. 7. ed. São Paulo: Revista dos Tribunais. 2011.

PEREIRA, Leonardo Rodrigo Oliveira. Crimes hediondos. Em: Âmbito Jurídico, Rio Grande, XXI, n. 172, maio 2018. Disponível em: <http://www.ambito-juridico.com.br/site/index.php?n_link=revista_artigos_leitura\&artigo_id=20549>. Acesso em nov. 2018.

SANTOS, Adriana Ribeiro dos; COIMBRA, José César. O Depoimento Judicial de Crianças e Adolescentes entre Apoio e Inquirição. Psicol. cienc. prof., Brasília, v. 37, n. 3, p. 595-607, Set 2017.

SEIÇA, Antônio Alberto Medina de. O Conhecimento Probatório do Co-Arguido. Boletim da Faculdade de Direito. Univ. de Coimbra. Coimbra Editora, 1999.

Pesquisa Pronta. Disponível em: <http://www.stj.jus.br/SCON/pesquisa_pronta/>. Acesso em: 03 dezembro 2018.

Recurso Especial: RE no 1.483.934 - TO 2014/0252428-6. Relator: Ministro Nefi Cordeiro. DJ: 16/06/2017. Disponível em: https://ww2.stj.jus.br/processo/revista/documento/mediado/?componen te $=$ MON\&sequencial $=73472589 \&$ num_registro $=201402524286 \& d a t a=20170621$. Acesso em: 03 dezembro 2018.

Habeas Corpus: HC 410.186 / TO 2017/0187114-4. Relator: Ministro Ribeiro Dantas. DJ: 24/05/2018. Disponível em: <https://ww2.stj.jus.br/processo/revista/documento/mediado/?componente $=$ ATC\&sequencial $=83462658 \&$ num_registro $=201701871144 \&$ data $=20180530 \&$ tipo $=91 \&$ formato $=$ PDF>. Acesso em: 03 dezembro 2018.

Recurso em Habeas Corpus: HC 94.036 / PR 2018/0011343-1. Relator: Ministro Ribeiro Dantas. DJ: 22/05/2018. Disponível em: <https://ww2.sti.jus.br/processo/revista/documento/mediado/? componente $=$ ATC\&sequencial $=83177662 \&$ num_registro $=201800113431 \&$ data $=20180530 \&$ tipo $=91 \&$ for mato $=$ PDF $>$. Acesso em: 03 dezembro 2018.

SZNICK, Valdir. Assédio Sexual e Crimes Sexuais Violentos. São Paulo: Ícone, 2011.

TÁVORA, Nestor \& ALENCAR, Rosmar Rodrigues. Curso de Direito Processual Penal. 7. ed. Salvador: Juspodivm, 2012. 